\title{
Development of Interactive Electronic Book Based Mathematics Teaching Materials on Cube and Cuboid in Junior High Schools
}

\author{
Suwarno $^{1}$, O D Sumintra ${ }^{2}$, N Pranuta Murnaka ${ }^{2}$, S Arifin ${ }^{2}$ \\ ${ }^{1}$ Faculty of Humanities, Universitas Bina Nusantara, Jakarta, Indonesia \\ ${ }^{2}$ Mathematics Education Department, STKIP Surya, Jakarta, Indonesia \\ ${ }^{1}$ suwarno2@binus.edu
}

\begin{abstract}
This research is motivated by the students' difficulties in imagining the building of three-dimensional space of cubes and cuboids especially when imagining the diagonal of space and the diagonal plane. Based on these problems researchers conducted research aimed at developing electronic book (e-book) based mathematics teaching materials on cube material and cuboids for the eighth grade of junior high school. E-book based mathematics teaching materials made by utilizing Adobe Acrobat Pro applicationis a document format in PDF form that can be inserted three-dimensional images and video. This research is a development by modifying the model of Thiagarajan (1974), comprising the steps of define, the design stage and develop stage. The subjects of the trial were the 8th grade students of SMP Negeri 2 Pagedangan. From the results of testingan $e$-book based mathematics teaching materials by the four validation experts, an average score of 4.42 was obtained from a maximum score of 5.00 with a very good category. From the results of the trial of e-book teaching materials by students obtained an average score of 4.06 from a maximum score of 5.00 with a good category. Overall, the interactive electronic books based on mathematics teaching materials are suitable to be used in learning cube and cuboid material.
\end{abstract}

Keywords: E- Book, Mathematics Teaching, Cube and Cuboid

\section{INTRODUCTION}

Mathematics is the queen as well as the servant of science which is the highest form of logic and provides asystem of organizing science that is logical and statements in the form of mathematical models [1]. At all levels of education from elementary school to college, mathematics is one of the fields in the list of lessons, even mathematics is taught in kindergartens informally [2]. Susanto [2] also states that the purpose of learning mathematics in schools is that students are skilled at using mathematics, besides that mathematics learning is intended to provide students with an emphasis on structuring reason in the application of mathematics to everyday life in the midst of society.

Given the importance of mathematics lessons, mathematics is one of the subjects that enter UAN.However, in fact many students find it difficult to understand and learn mathematics, even students who do not pass the UAN are often encountered because their mathematical 
values are below the specified graduation standard [3]. Susanto [2] also stated that the weakness of the learning process is a problem faced in the world of education.

Based on the results of observations at SMP Negeri 2 Pagedangan, Tangerang Regency, it was obtained information that some students there found it difficult to understand existing modules, sometimes they were also difficult to imagine building three-dimensional space such as imagining the diagonal of the space and diagonalfields contained in cubes and cuboids. The researcher also conducted an interview with one of the teachers who taught in class VIII, according to him also most students had difficulty to imagine building three-dimensional space.Therefore, an effortis neededto improve the quality of students' mathematical competencies, especially in building material.One of the improvement efforts that can be done is by making learning media for students that are innovative and creative which can motivate students to learn. With the rapid development of technology in the world, it is expected that in the world of education, they will also be able to use it.As Daryanto argues [4] which states that in the era of technological development as it is today, teachers need to have the skills and confidence in using technology. One of them is by making learning media for students based on computer technology, namely by making an e-book based mathematics teaching materials.

Student learning success is positively influenced by the material presentation model, such as presenting material that is more fun, not boring, interesting, and easily understood by students [2]. The use of interesting, innovative, and creative learning media is one of the supporting factors for successful learning in schools that can increase students' interest to learn an object [5].

This is in line with what is expressed by Arsyad [6] which states that as additional helpers inlearning, the use ofcomputers includes presenting information on the contents of the subject matter, training, or both.With computers we can create audio-visual teaching materialsso that students can easily learn the material independently.In addition, we are also able to create graphical views and generate three-dimensional image views with precision.Prastowo [7] also explained that as a learning medium, computer-based interactive teaching materials have five advantages: interactive, providing an individual affective climate, increasing learning motivation, giving feedback, and because computer-based interactive teaching materials are programmed for independent learning, then control utilization is entirely on its users. One of the learning media that can be developed is electronic book (e-book) [5]. E-book stands for electronic book, a reading book published in an electronic format that allows people to have instant access to books quickly because they can be downloaded directly from the [8].

From the description of the above problems, the researcher tries to conduct research on the development ofinteractive electronic textbookbased teaching materialson the material of cubes and Cuboids for class VIII SMP. Thisteaching mathematics course basedon interactive electronic bookscan be used not only to help teachers deliver the subject matter but also to help students understand three-dimensional space building especially in cube and beam material and make students more interested in learning mathematics.

\section{LITERATURE REVIEW}

\subsection{Learning Media}

Literally the media comes from Latin medius which means 'middle', 'intermediary' or 'introduction' whereas in Arabic, the media meansas an intermediary or messenger of messages from the sender to the recipient [6]. Daryanto [4] stated that learning media is 
everything as a channel for messages (learning materials) that can stimulate attention, interest, thoughts, feelings, learners in learning activities so that learning objectives can be achieved.

\subsection{Development of teaching materials}

Teaching materials are a very important part of the overall learning process [9]. Teaching materials are used by educators to assist in teaching and learning activities so as to create an atmosphere that allows students to learn, in the form ofinformation, tools and written and unwritten texts that have been systematically arranged [10], Basically, the development of teaching materials can be viewed from two dimensions, namely the dimension of involvement of instructors or educators in learning activities and the dimensions of teaching materialsused in learning, so that each form of learning activities requires different teaching materials in accordance with the learning [10].

\subsection{Electronic Books}

E-book stands forelectronic book, a reading book published in an electronic format that allows people to have instant access to books faster because they can be downloaded directly from the internet [8]. E-books can be published in various file formats,such as plaintext, PDF, Rich, Text Format, as image files, etc. [8]. E-book is a collection of text, images or multimedia summarized simply in the form of electronic books or digital books, generally Ebooks present a collection of text, images or multimedia into plain text format, * pdf, * jpeg, * lit and * html [5].

\section{METHOD}

The teaching material developed in this studyuses development with the 4D model (Define, Design, Develop and Disseminate). 4D model development consists of four stages, namely the definition phase (define),design (design), development (develop), and dissemination (disseminate) [11]. Learning the 4D model wasdeveloped by Thiagarajan 1974. However, in this study only up to the stage of development (develop). This study was not until the stage of deployment (disseminate) because the researchers did not disseminate teaching materials have been developed, it is due time that does not allow researchers to do the spread (disseminate). In this study the tools developed wereinteractive electronic books based on mathematics teaching materials. The research instruments used in this study in cluded validation sheets, student response questionnaire sheets, and observation sheets.

\subsection{Define}

Activities at this stage aim to establish and define the requirements for developing mathematics-based teaching materials interactive electronic books.To determine and define the requirements for developing instructional materials the first step is by analyzing student problems in the material to be developed. In this study limited to cube and beam material for the eighth grade of junior high school. The defining stage consists of five steps: front-end analysis, learner analysis, concept analysis, task analysis, and specifying instructional objectives. 


\subsection{Design}

At the design stage (design) Thiagarajan split into four activities, namely the construction of test criterion, media selection,format selection, and initial design. At the criterion test construction stage, researchers compile a test of learning outcomes on cube and beam material. Preparation of the test is from the analysis task and concept analysis described in the specification of learning objectives. $\mathrm{n}$ the stages of media selection, researchers choose the learning media in accordance with the material and characteristics of learners. The selection of media is adjusted to the analysis of tasks and concepts. The format selection stage is the selection of the form of learning that is adapted to the learning media used. While the initial design stage, researchers designed the presentation of material with interactive electronic books based on mathematics teaching materials and develop learning steps to be under taken. The initial design in question was a mathematics teaching material developed which was called draft I.

\subsection{Develop}

The objective at this stage of development is to produce interactive mathematics-based instructional materials. Activities at this stage include the validation of interactive electronic books based on mathematics teaching materials and the testing of interactive electronic books based on mathematics teaching materials. The purpose of the validation of teaching materials is to find out whether or not the teaching material developed is valid. Validation of this teaching material is carried out by several experts or experienced experts to assess the teaching materials that have been made.

The trial was carried out after obtaining the validation results by the four respondents and was corrected so that the teaching material was feasible to be tested. The purpose of this trial is to find out the students' response to the use of mathematics teaching materials and theresults are usedto improve the mathematics teaching materials that have been made. In this test the researcher chose one of the eighth grade, junior high school in Tangerang who had a computer laboratory as the subject of a trial of mathematics teaching materials, namely SMP Negeri 2 Pagedangan class 8 .

Teaching materials that have been made (draft I) and validated by the four respondents are then corrected and the results are obtained (draft II). Subsequently tested on the subject of the study that has been determined. The trial conducted aims to get responses from students to the teaching materials that have been made. The responses given by students were then analyzed and obtained draft III (the results of the development of teaching materials).

\subsection{Disseminate}

In this research material development using 4-D development model developed by Thiagarajan 1974. However, there are steps that are not performed in this research that the deployment phase (disseminate), this was due to the time researchers were not allowed to perform the spread (disseminate).

\subsection{Instruments}

In this study the research instrument used consisted of non-test instruments in the form of validation questionnaires, student response questionnaires, and observation sheets. This 
validation questionnaire is used to improve the design of teaching materials used. Student response questionnaire isused to determine students' responses during learning usinginteractive electronic booksbased on mathematics teaching materials. Observation sheetsfor reference references that must be filled by observers used to determine the activities of teachers and students during the learning activities. This observation is carried out to obtain or collect data and information that is not observed directly by the researcher during the learning activities.

\subsection{Data Analysis}

Data processing consists of data processing result of questionnaire and data processing result of observation.Data obtained through questionnaires that have been given to respondents were analyzed by calculating the average score of each statement given. The assessment for each category in the questionnaire consists of 5 (five) rating scales, that is, not good (score 1), not good (score 2), good enough (score 3), good (score 4), and very good (score 5) [11].

Observation data is data obtained through observation activities, namely teacher and student activities during learning. The data has been obtained is then processed and analyzed descriptively. The implementation of the activities of each step is made in the form of a table then the data is presented in the form of an average score as follows.

$$
\bar{x}=\frac{\sum \text { Obtained Scale }}{\text { number of respondents }}
$$

The score assessment indicator statement questionnaire used is as follows.

Table 1. Indicators of Score Statement Rating Score.

\begin{tabular}{cc}
\hline Value & Information \\
\hline $1.0 \leq \bar{x} \leq 1.8$ & Not good \\
$1.8<\bar{x} \leq 2.6$ & Not good \\
$2.6<\bar{x} \leq 3.4$ & Pretty good \\
$3.4<\bar{x} \leq 4.2$ & Good \\
$4.2<\bar{x} \leq 5.0$ & Very good \\
\hline
\end{tabular}

\section{RESULT AND DISCUSSION}

The validation ofinteractive electronic books based on interactive electronic books was carried out by four experts or experienced experts. After obtained, the first draft was further validated by a team of experts (validator) and improvements made in accordance with the input validators to obtain draft II devices. In this design validation uses 4 respondents in the fields of mathematics, education technology,multimedia, and mathematics teachers who test mathematics teaching materials. The purpose of the validation of mathematics teaching materialsby thefour experts is to know the advantages and disadvantages ofinteractivemathematics-basedinteractive booksthat have been made to be repaired.

Overall, the results of the four expert tests are seen from the aspects and indicators can be seen in the table below: 
Table2. Results of Testing Analysis by the Four Experts Overall.

\begin{tabular}{clcc}
\hline \multicolumn{1}{c}{ Aspect } & \multicolumn{1}{c}{ Indicator } & Score & Criteria \\
\hline Feasibility & Material compatibility with SK and KD & 4.75 & Very good \\
of Content & The truth of concept / matter & 4.75 & Very good \\
& The suitability of the material sequence & 4.75 & Very good \\
& Constant use of terms and symbols & 4.50 & Very good \\
Format & Cf & 4.25 & Very good \\
Teaching & Clear numbering system & 4.25 & Very good \\
Materials & Visually appealed & 4.75 & Very good \\
& Balance between text and illustrations & 4.25 & Very good \\
& Type and size of letters & 4.50 & Very good \\
& Writing settings (layout, spaces, space and & 4.00 & Good \\
& images) & & \\
Language & Good and right grammar truths & 3.75 & Good \\
& Conformity of sentences with the level of & 4.50 & Very good \\
& thinking and reading ability and age of & & \\
& students & & \\
& The simplicity of sentence structure & 4.25 & Very good \\
& Use of communicative language & 4.50 & Very good \\
& $\quad$ Average & 4.42 & Very good \\
\hline
\end{tabular}

Based on Table 2, content feasibility category, the format of teaching materials, and the language of mathematics teaching materials basedon interactive electronic booksobtained very good criteria with an average score of 4.42 .

The next step is to test the mathematics materials to students at school.The results of the experimental test of mathematics to students also greatly influence in the successful development of this mathematical material.Result of feasibility test of mathematics-based materialInteractive electronic booksthat have been conducted by students of SMP Negeri 2 Pagedangan class 8 can be seen in the following table.

Table 3. Results of Trial of Mathematics Teaching Materials by Students.

\begin{tabular}{clcc}
\hline No & \multicolumn{1}{c}{ Question } & Score & Information \\
\hline 1 & $\begin{array}{l}\text { Do you feel happy about } \\
\text { Learning uses interactive material on cube } \\
\text { \&cuboid material }\end{array}$ & 4,10 & Good \\
$\quad \begin{array}{l}\text { a. Interactive teaching materials } \\
\text { b. Learning atmosphere in class }\end{array}$ & 3.90 & Good \\
$\quad \begin{array}{l}\text { c. How teachers teach. } \\
\text { Do you think the things below are new } \\
\text { a. Learning uses interactive material on cube }\end{array}$ & 3.90 & $\begin{array}{c}\text { Good } \\
\text { \&cuboid material }\end{array}$ \\
$\quad \begin{array}{l}\text { b. Interactive teaching materials } \\
\quad\end{array}$ & 3.60 & New \\
\end{tabular}


c. Learning atmosphere in class

4 Can you understand the language used on
a. Interactive teaching materials

5 Are you interested in the appearance (writing, drawing, location of images) contained in interactive materials

6 Are learning activities that have been done can open, grow or improve knowledge?

Based on Table 3 theresults of the trial of mathematics teaching materials by students can be seen that the overall assessment of students obtained an average score of 4.06 in the good category.

\section{CONCLUSION}

Based on the results description on of mathematics teaching materials based on interactive electronic books research and development, itcan be concluded that there have been generated interactive electronic books based on mathematics teaching materialson cube and beam material for class VIII SMP with PDF format. Development of mathematics teaching materials based on interactive electronic books through three phases, namely the definition (define), stage design (design), and the stage of development (develop). Results of analysis of interactive mathematics teaching materials basedon electronic booksby the four experts obtained an average score of 4.42 with a very good category. Results of analysis of experimental test of mathematics basedon interactive electronic bookby students obtained an average score of 4.06 in the good category. Based on the results of the assessment, mathematics teaching materials basedon interactive electronic booksworthy of usein learning the material of cubes and cuboids.

\section{REFERENCES}

[1] J. S. Suriasumantri, Filsafat Ilmu, 1st ed. Jakarta: Sinar Harapan, 1984.

[2] A. Susanto, Teori Belajar dan Pembelajaran di Sekolah Dasar. Jakarta: Kencana Prenada Media Group, 2013.

[3] Mujiyati, Buku Pintar Matematika. Yogyakarta: Familia, 2012.

[4] Daryanto, Media Pembelajaran. Bandung: Satu Nusa, 2010.

[5] B. Triyono, Pengembangan Interaktif e-Book dari Sisi Pedagogik, Teknologi Perangkat Lunak Serta Media yang Digunakan. Yogyakarta: UniversitasNegeri Yogyakarta, 2012.

[6] A. Arsyad, Media Pembelajaran. Jakarta: PT Raja Grafindo Persada, 2014.

[7] A. Prastowo, PengembanganBahan Ajar Tematik. Jakarta: Kencana Prenada Media Group, 2014.

[8] Tim EMS, Kamus Komputer Lengkap. Jakarta: PT Elex Media Komputindo, 2015. 
[9] Y. Ramdani, "Pengembangan Instrumen dan Bahan Ajar untuk Meningkatkan Kemampuan Komunikasi, Penalaran, dan Koneksi Matematis dalam Konsep Integral," J. Penelit. Pendidik., vol. 13, no. 1, pp. 44-52, 2012.

[10] B. Triyono, Pengembangan Bahan Ajar. Materi Diklat Training Of Trainer Calon Tenaga Pengajar/Dosen Lingkungan Badiklat PerhubunganTahun. Yogyakarta: Universitas Gajah Mada, 2009.

[11] Hobri, Metodologi Penelitian Pengembangan (Aplikasi Pada Penelitian Pendidikan Matematika). Jember: Pena Salsabila, 2010. 